\title{
Least limiting water range, S-index and compressibility of a Udalf under different
}

\section{management systems}

\author{
Cláudia Liane Rodrigues de Lima ${ }^{1 *} \odot$, Patrícia Bianca Dupont ${ }^{1}$, Clenio Nailto Pillon ${ }^{2}$, Ezequiel Cesar Carvalho Miola ${ }^{3 \odot}$
}

'Universidade Federal de Pelotas/FAEM - Depto. de Solos, C.P. 354 - 96010-900 - Pelotas, RS - Brasil.

2Embrapa Clima Temperado, Rod. BR 392, km 78, C.P. 403 - 96010-971 - Pelotas, RS - Brasil.

${ }^{3}$ Universidade Federal do Rio Grande, Av. Marechal Floriano Peixoto, 2236-96170-000 - São Lourenço do Sul, RS -

Brasil.

*Corresponding author <clrlima@yahoo.com.br>

Edited by: Silvia del Carmen Imhoff

Received June 19, 2017

Accepted February 11, 2019
ABSTRACT: Agricultural areas in the region of Turuçu, on the Southeast Hillside in the state of Rio Grande do Sul (RS), Brazil present many examples of soil physical degradation. Accordingly, strategies aimed at evaluating and ameliorating the structural quality of soils should be developed to ensure the sustainable use of these areas. This study aimed to evaluate the least limiting water range (LLWR), S-index, compressibility parameters, organic carbon and the organic matter granulometric fractions of a Udalf under different agricultural uses. Soil samples with disturbed and non-disturbed structure from the 0.00 to $0.10 \mathrm{~m}$ layer were collected on farms in the Southeast Hillside, Turuçu region, RS, for analyzing soil under: i) conventional system of corn after tobacco crop, (CT); ii) conventional system of corn after native field (CNF), iii) native field (NF) and iv) native area (NA). Both the CT and the CNF systems had a negative influence on the values of bulk density, soil porosity, least limiting water range, compressibility parameters and total organic carbon, coarse fraction carbon and carbon associated with minerals.

Keywords: soil quality, soil physics, soil structure, soil compaction

\section{Introduction}

In the south of Brazil the conventional system for cultivating corn and tobacco has long been deployed by family farms. This land use system is known to influence bulk density, penetration resistance, soil porosity, aggregation, organic carbon (Silva et al., 2016; Rosemary et al., 2017) and crop yield (Mishra et al., 2015; Cecagno et al., 2016). However, studies whose aim is to evaluate the impact of these activities on the soil quality in this region are scarce.

The least limiting water range (LLWR) is defined as the range in soil water content within which limitations to plant growth associated with water potential, aeration and mechanical resistance to root penetration are small. The LLWR has been proposed as an index of the structural quality of soils for crop growth (Silva et al., 1994). Within the context of the LLWR, the impact of changes in soil structure on plant growth is strongly influenced by water content. Studies on the critical values of bulk density and the LLWR (Guedes-Filho et al., 2014) to develop crops and evaluate soil physical quality have been addressed (Asgarzadeh et al., 2010; Cecagno et al., 2016).

Dexter $(2004 a, b)$, considering the water retention curve (WRC) as an efficient parameter of soil physical quality influenced by the tillage systems, proposed the S-value or S-index (Rossetti et al., 2013, Islabão et al., 2016 and Naderi-Boldaji and Keller 2016). According to Dexter (2004a) the S-index is the WRC inclination value at its inflexion point. De Jong van Lier (2014) pointed out that despite being static, this parameter is mathematically associated with soil bulk density and soil porosity.

Machinery traffic associated with the management system can influence parameters obtained from the uniaxial compression curves such as the load sup- port capacity, soil susceptibility to compaction and degree-of-compactness (Reichert et al., 2016; Somavilla et al., 2017) and its implications for soil structure and root development. The aim of this research was to evaluate the least limiting water range, S-index, compressibility parameters and organic carbon of a Udalf under different management systems, in the Southeast Hillside, RS, Brazil.

\section{Materials and Methods}

The study was carried out on a farm located in the city of Turuçu, RS, Brazil. The sampled area is located in a watershed belonging to the Turuçu river ba$\sin$, which is a source of water supply to the city, located between geographical coordinates $31^{\circ} 25^{\prime} \mathrm{S}$ and $52^{\circ} 15^{\prime}$ $\mathrm{W}$ (altitude: $30 \mathrm{~m}$ ) with an area of approximately 1,580 ha (Figure 1).

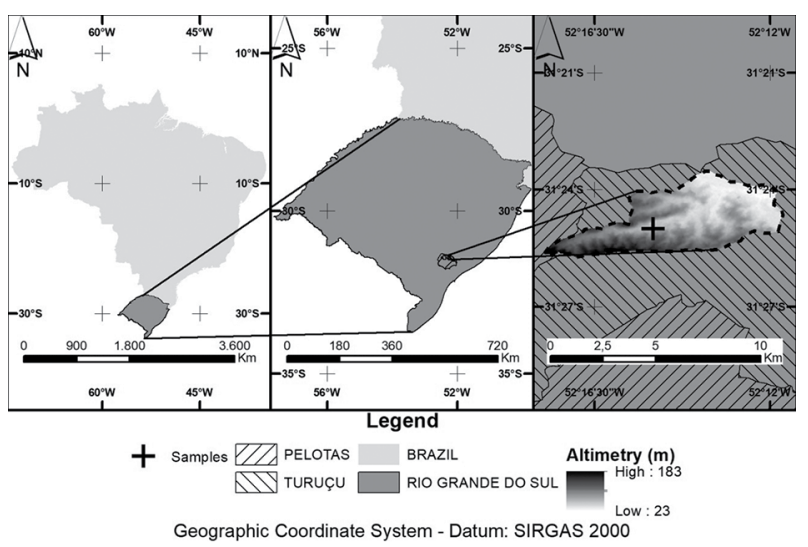

Figure 1 - Geographical location at watershed and respective studied site. 
The climate in the region is $\mathrm{Cfa}$, according to Köppen classification representing a subtropical marine environment with humid summers and humid or super-humi winters. The rainfall and the annual average temperature in the region are $1,400 \mathrm{~mm}$ and $18^{\circ} \mathrm{C}$, respectively (Alvares et al., 2013). The soil is classified as a Udalf (USDA-NRCS, 2010), with sandy loam texture and organic carbon varying from 6 to $18 \mathrm{~g} \mathrm{~kg}^{-1}(0.00$ to $0.10 \mathrm{~m}$ depth) (Table 1).

The treatments comprised soil under: i) conventional system with corn after tobacco crop, with a history of succession of strawberry, tobacco and corn crops from 2004 to 2010 (CT); ii) conventional system with corn crop after native field (first corn crop followed by grazing after 30 years of native field) $(\mathrm{CNF})$; iii) grazing, on native field, for 30 years (NF) and iv) native area with predominance of vegetation, whose type of soil, relief and other characteristics are representative of the original condition of the remaining areas under evaluation (NA).

From the 0.00 to $0.10 \mathrm{~m}$ soil layer (intensively modified with respect to physical attributes under a crop root zone management system) of each area, samples with disturbed structure were collected for granulometric (pipette method according to Gee and Bauder, 1986), and soil total organic carbon (TOC) evaluation (Table 1). To determine bulk density (Bd), total porosity (Tp) (sum of soil macroporosity and soil microporosity), penetration resistance (PR), water retention curve (WRC), least limiting water range (LLWR) and the S-index in the same areas, 96 non-disturbed samples were collected using volumetric rings $0.05 \mathrm{~m}$ in diameter and $0.03 \mathrm{~m}$ in height (24 samples per treatment $\times 8$ suction potentials).

To evaluate the LLWR, the undisturbed samples were saturated with water for $24 \mathrm{~h}$ and submitted to matric suction of $-1 ;-2 ;-4$ and $-6 \mathrm{kPa}$ ), on a tension table and $-10 ;-33 ;-100$ and $-1,500 \mathrm{kPa}$ in a Richards pressure chamber (Klute, 1986). After equilibration between the potential applied and the soil water content, each sample was weighed and the PR determined in the laboratory, at three sites equidistant from the center of the sample, using an electronic penetrometer with constant soil penetration velocity $\left(10 \mathrm{~mm} \mathrm{~min}^{-1}\right)$ and acquisition of automated data (Tormena et al., 1998).

Table 1 - Mean values of particle size distribution (clay, silt and sand) and total organic carbon content (TOC) of an Udalf under different management systems (0.00 to $0.10 \mathrm{~m}$ depth).

\begin{tabular}{|c|c|c|c|c|}
\hline Management systems $^{1}$ & Clay & Silt & Sand & TOC \\
\hline & \multicolumn{4}{|c|}{$\mathrm{g} \mathrm{kg}^{-1}$} \\
\hline CT & 94.1 & 206.4 & 699.5 & 6.3 \\
\hline CNF & 134.5 & 214.4 & 651.1 & 9.7 \\
\hline $\mathrm{NF}$ & 152.1 & 240.2 & 607.7 & 17.5 \\
\hline NA & 178.0 & 270.1 & 551.9 & 18.2 \\
\hline
\end{tabular}

${ }^{1} \mathrm{CT}=$ soil with corn crop after tobacco crop under a conventional system; $\mathrm{CNF}=$ soil with corn crop after native field under a conventional system; $\mathrm{NF}=$ native field soil and NA = native area.
Later on, the samples were oven dried at $105{ }^{\circ} \mathrm{C}$ to determine $\mathrm{Bd}$ (Blake and Hartge, 1986), gravimetric water content (Gwc) (Gardner, 1986), volumetric water content $(\theta)$ and soil porosity. The measured WRC dada points were adjusted by employing the van Genuchten model (1980), aided by the computer program Soil Water Retention Curve (Dourado Neto et al., 1990):

$\theta=\theta$ res $+\frac{\theta \text { sat }-\theta \text { res }}{\left[1+\left.|\alpha \times| \psi\right|^{n}\right]^{m}}$

$\theta=$ soil volumetric water content $\left(\mathrm{m}^{3} \mathrm{~m}^{-3}\right)$; $\theta$ res, $\theta$ sat $=$ residual and saturated soil volumetric water content, respectively $\left(\mathrm{m}^{3} \mathrm{~m}^{-3}\right) ; \psi=$ matric suction $(\mathrm{kPa}) ; \alpha, m$ and $n=$ empirical parameters.

The available water (AW) was calculated using the top and bottom limits defined by the volumetric water content at field capacity $\left(\theta_{F C}=-10 \mathrm{kPa}\right)$ and volumetric water content at permanent wilting point $\theta_{P W P}=-1,500$ $\mathrm{kPa}$ ) respectively. From the WRC, the S-index was obtained according to Dexter (2004a):

$S=-n\left(G w c_{\text {sat }}-G w c_{r e s}\right) \times\left(1+\frac{1}{m}\right)^{-(1+m)}$

$S=S$ index; $G w c_{\text {sat }}$ and $G w c_{\text {res }}=$ soil gravimetric water content at saturation (sat) and residual (res) $\left(\mathrm{g} \mathrm{g}^{-1}\right)$, respectively; $m$ and $n=$ empirical parameters.

To determine the LLWR, the volumetric water content $(\theta)$ was adjusted as a function of the suction potential (expressed as a module) and bulk density, according to Silva et al. (1994):

$\theta=\exp (a+b B d) \psi^{c}$

$\theta=$ volumetric water content $\left(\mathrm{m}^{3} \mathrm{~m}^{-3}\right) ; B d=$ bulk density $\left(\mathrm{Mg} \mathrm{m}^{-3}\right) ; \psi=$ matric suction $(\mathrm{kPa}) ; a, b$ and $c=$ empirical parameters.

The PR curve was adjusted using the non-linear equation proposed by Busscher (1990):

$\mathrm{PR}=d \theta^{e} B d^{f}$

$P R=$ penetration resistance $(\mathrm{kPa}) ; \theta=$ volumetric water content $\left(\mathrm{m}^{3} \mathrm{~m}^{-3}\right) ; B d=$ bulk density $\left(\mathrm{Mg} \mathrm{m}^{-3}\right) ; d, e$ and $f$ $=$ empirical parameters.

The PR values were plotted as a function of $\mathrm{Bd}$. The LLWR indicated as the top limit, the lowest volumetric water content $(\theta)$ obtained at field capacity $\left(\theta_{F C}\right.$ $=-10 \mathrm{kPa}$ ) or in $10 \%$ aeration porosity and, as the bottom limit, the highest $\theta$ value in the $2,000 \mathrm{kPa}$ (penetration resistance) or at the permanent wilting point $\left(\theta_{P W P}\right.$ $=-1,500 \mathrm{kPa})$. The critical soil bulk density $\left(B d_{c}\right)$, which corresponded to the $\mathrm{Bd}$ value at which the LLWR is zero, was defined by the intersection of equations that determined the top and bottom limits of the LLWR (Silva et al., 1994).

Additionally, to evaluate the compression parameters, undisturbed samples were collected randomly from 
each sampling point in the 0.00 to $0.10 \mathrm{~m}$ layer, with a ring $0.05 \mathrm{~m}$ in diameter and $0.03 \mathrm{~m}$ in height, comprising 54 samples.

In the laboratory, the samples were saturated with water for $24 \mathrm{~h}$ and submitted to matric suction $(\psi)$ : -10 kPa, in Richards' pressure chambers (Klute, 1986). After equilibration, each sample, excluding the natural area (NA) soil samples (justification: problems in the soil samples), was weighed and submitted to the uniaxial compression test which consists of successive and continuous application of established pressures 25, 50, 100, $200,400,800$ and $1,600 \mathrm{kPa}$ (Silva et al., 2007) aided by an automatic consolidometer.

The soil compactness-degree (CD) was calculated from the relationship between the initial $\mathrm{Bd}$ and that obtained with pressure after applying $200 \mathrm{kPa}$ (Håkansson, 1990), 1,600 kPa (Reichert et al., 2009) and the one referring to the preconsolidation pressure (Lima et al., 2012). Additionally, the same samples with disturbed structure were air dried, for about $72 \mathrm{~h}$, sieved through a 9.52 $\mathrm{mm}$ mesh sieve and, later, sieved through a $2 \mathrm{~mm}$ mesh sieve and ground for TOC analysis by dry oxidation, and the results were expressed by the relationship of mass/ volume through Bd correction.

Granulometric physical fractioning was carried out according to Cambardella and Elliott (1992). The carbon resulting from the material retained by the sieve $>0.053$ $\mathrm{mm}$ corresponded to the coarse fraction carbon (CFC), while the carbon associated with minerals (CAM) was obtained from the difference between TOC and CFC.

Variance analysis was performed on all other data sets using the Sisvar software analysis program (version 5.3, build 75) (Ferreira, 2011). Differences between treatment means were considered statistically significant at a $p$ value $\leq 0.05$ using the least significant difference.

\section{Results and Discussion}

The coefficients from the least-squares fit of the soil water retention, penetration resistance curve and WRC according to the van Genuchten (1980) model are shown in Table 2 . The data were adjusted appropriately to the models used. The $\theta_{\text {res }}$ and $\theta_{\text {sat }}$ values were lower in the CT. The lower values in clay content and TOC in this soil use system (Table 1) may be related to this result. The structural degradation caused by the continuous soil revolving and soil organic matter (MOS) exposure under the CT favor the destruction of the MOS, resulting in a decrease in the soil adsorption capacity of the soil, and consequently, in $\theta_{\text {res }}$. The $\theta_{\text {sat }}$ value indicates that the conventional system presented the lowest porosity in comparison to the land use systems.

The corn after the tobacco crop in soil under conventional system $(\mathrm{CT})$ presented higher $\mathrm{Bd}$ and a higher percentage of differences relative to NF and NA, which is related inversely to the $\mathrm{Tp}$ (Table 3 ). The soil porous system is directly linked to the soil structure and exhibits the effect of management systems (Pires et al., 2017).
The highest $\mathrm{Bd}$ values in the CT is due to the higher accumulated soil pressure exerted by the intense traffic of machines during the period of use of this soil.

The CT had the lowest value of $\theta_{F C}$ and $\theta_{P W P}$, while the other systems presented similar values. Despite this, there was no difference in the plant available water when the management systems were compared (Table 3). The AW was not significantly altered because the reduction in $\theta_{F C}$ was accompanied by a reduction in the $\theta_{P W P}$ in similar proportions.

The S-index revealed no significant differences regarding management systems, which usually occurs in soils with coarse texture, as confirmed by Reynolds et al.

Table 2 - Mean values of coefficients of adjustment according to van Genuchten (1980) model $\left(\theta_{\text {res }}, \theta_{\text {sat }}, \alpha, m, n\right)$, soil penetration resistance curve $(a, b, c)$ and water retention curve $(d, e, f)$ of an Udalf under different management systems.

\begin{tabular}{lccccc}
\hline Equation & Coefficient & $\mathrm{CT}$ & $\mathrm{CNF}$ & $\mathrm{NF}$ & $\mathrm{NA}$ \\
\hline$\theta$ & $\theta_{\text {res }}$ & 0.06 & 0.14 & 0.15 & 0.11 \\
$=\theta_{\text {res }}$ & $\theta_{\text {sat }}$ & 0.21 & 0.31 & 0.37 & 0.33 \\
$+\frac{\theta_{\text {sat }}-\theta_{\text {res }}}{\left[1+\left(\alpha \times\left.|\psi|\right|^{n}\right]^{m}\right.}$ & $\alpha$ & 0.12 & 0.26 & 0.01 & 0.01 \\
& $\mathrm{~m}$ & 0.21 & 3.35 & 5.02 & 1.71 \\
\hline$\theta=\exp (a \times b B d) \psi^{c}$ & $n$ & 2.25 & 3.18 & 3.20 & 6.24 \\
\hline & $a$ & -2.63 & -1.66 & -1.03 & -0.93 \\
\hline & $b$ & 0.12 & -0.19 & -0.52 & -0.64 \\
\hline \multirow{2}{*}{$P R=d \theta^{\mathrm{e} B d^{f}}$} & $c$ & -0.17 & -0.14 & -0.14 & -0.13 \\
& $d$ & 0.00 & 0.05 & 0.21 & 0.39 \\
& $e$ & -1.36 & -1.38 & -1.03 & -0.67 \\
\hline
\end{tabular}

$\mathrm{CT}=$ soil with corn crop after tobacco crop under a conventional system; $\mathrm{CNF}=$ soil with corn crop after native field under a conventional system; $N F$ $=$ native field soil and $\mathrm{NA}=$ native area. $\theta_{\text {res' }}, \theta_{\text {sat }}=$ residual and saturated soil volumetric water content $(\theta)\left(\mathrm{m}^{3} \mathrm{~m}^{-3}\right) ; \psi=$ matric suction $(\mathrm{kPa}) ; \mathrm{PR}=$ penetration resistance $(\mathrm{kPa}) ; \mathrm{Bd}=$ bulk density $\left(\mathrm{Mg} \mathrm{m}^{-3}\right)$.

Table 3 - Mean values of bulk density (Bd), total porosity (Tp), soil water content at field capacity $\left(\theta_{F C}\right)$ and at permanent wilting point $\left(\theta_{P W P}\right)$, available water $(A W)$ and S-index of an Udalf under different management systems.

\begin{tabular}{|c|c|c|c|c|c|c|}
\hline \multirow{2}{*}{$\begin{array}{l}\text { Management } \\
\text { systems }^{1}\end{array}$} & $\mathrm{Bd}$ & $\mathrm{Tp}$ & $\theta_{F C}$ & $\theta_{P W P}$ & AW & S \\
\hline & $\mathrm{Mg} \mathrm{m}^{-3}$ & & \multicolumn{3}{|c|}{$-m^{3} m^{-3}$} & 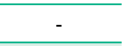 \\
\hline CT & $1.65 \mathrm{a}$ & $0.35 \mathrm{c}$ & $0.19 b$ & $0.10 \mathrm{c}$ & $0.09 \mathrm{~ns}$ & $0.036 \mathrm{~ns}$ \\
\hline$\Delta_{\text {ref. }} N F(\%)$ & +17.9 & -20.5 & -36.7 & -54.5 & +12.5 & -64.7 \\
\hline$\Delta_{\text {ref. }} N A(\%)$ & +15.4 & -14.6 & -34.5 & -37.5 & -30.8 & -50.0 \\
\hline
\end{tabular}

$\begin{array}{lllllll}\text { CNF } & 1.50 \mathrm{~b} & 0.40 \mathrm{~b} & 0.26 \mathrm{a} & 0.18 \mathrm{ab} & 0.08 \mathrm{~ns} & 0.082 \mathrm{~ns}\end{array}$

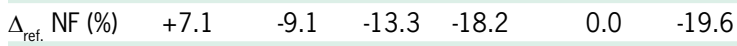

$\Delta_{\text {ref. }} N A(\%) \quad+4.9 \quad-2.4 \quad-10.3 \quad+12.5 \quad-38.5 \quad+13.9$

$\begin{array}{lllllll}\text { NF } & 1.40 c & 0.44 a & 0.30 a & 0.22 a & 0.08 \mathrm{~ns} & 0.102 \mathrm{~ns} \\ \mathrm{NA} & 1.43 \mathrm{bc} & 0.41 \mathrm{ab} & 0.29 \mathrm{a} & 0.16 \mathrm{~b} & 0.13 \mathrm{~ns} & 0.072 \mathrm{~ns}\end{array}$

${ }^{1} \mathrm{CT}=$ soil with corn crop after tobacco crop under a conventional system; $\mathrm{CNF}=$ soil with corn crop after native field under a conventional system; NF = native field soil and NA $=$ native area. $\Delta_{\text {ref. }}(\%)=$ increase $(+)$ or decrease $(-)$ as a percentage of NF. Means followed by the same small letter in the column, did not differ from each other in the LSD test at the $5 \%$ level. 
(2009). The highest absolute values suggesting the most suitable physical conditions were observed in NF (Table 3) presenting better soil quality (Dexter, 2004a). However, only CT was considered to be likely to signalize structural degradation problems (Table 3), by presenting a value close to 0.035 , which is considered by Dexter (2004a) to restrict crop development.

Considering the mean bulk density, the LLWR was similar in all evaluated management systems. All areas presented critical values for the development of plants with low aeration porosity and high resistance to penetration (Figure 2).

The LLWR under CT was defined at the top limit by $\theta_{F C}$ and at the bottom limit by $\theta_{P R}$ (Figure 2A). Under $\mathrm{CNF}$, it was defined by $\theta_{F C}$ (top limit) and in values over $1.25 \mathrm{Mg} \mathrm{m}^{-3}$ the $\theta_{P W P}$ was substituted by $\theta_{P R}$ (bottom limit) (Figure 2B). In the soil under NF, the LLWR was defined by $\theta_{F C}$ at the top limit and the $\theta_{P R}$ substituted $\theta_{P W P}$ at the bottom limit when the $\mathrm{Bd}$ was higher than 1.18 $\mathrm{Mg} \mathrm{m}^{-3}$ (Figure 2C). The LLWR in the soil under NA was defined by $\theta_{F C}$ at the top limit and $\theta_{P R}$ substituted $\theta_{P W P}$ at the bottom limit when the $\mathrm{Bd}$ was higher than $1.20 \mathrm{Mg}$ $\mathrm{m}^{-3}$ (Figure 2D). Under all systems the $\mathrm{Bd}$ was positively related to the $\theta_{P R}$ but negatively related to $\theta_{A P}$.

The $\mathrm{Bd}$ values where the LLWR was considered zero and the limitations converged were $1.64 \mathrm{Mg} \mathrm{m}^{-3}$, $1.51 \mathrm{Mg} \mathrm{m}^{-3}, 1.38 \mathrm{Mg} \mathrm{m}^{-3}$ and $1.36 \mathrm{Mg} \mathrm{m}^{-3}$ for the CT, $\mathrm{CNF}, \mathrm{NF}$ and NA systems, respectively (Figure 2). Considering the mean bulk density, the LLWR was similar under all the evaluated management systems. All areas presented low aeration porosity, high resistance to penetration and critical values for the development of plants (Table 3 and Figure 2). The occurrence of $\mathrm{Bd}>$ $\mathrm{Bd}_{\mathrm{c}}$ signals the soil structural degradation, which can also reduce plant growth and productivity. With the exception of the CT management system, where the results between the $S$ index and the LLWR are corroborative, the other systems, contradict each other as per two soil quality indexes. According to the $\mathrm{S}$ index, the soil structural condition is favorable to the growth of roots, considering the Bdc determined by the LLWR. Although these indices are determined in different ways, which can justify this behavior, both have the same purpose of indicating the soil structural quality. This divergence may suggest higher or lower efficiency of these tools for this function. However, it is worth mentioning that they are already highly respected and used in countless studies that evaluate soil quality. It is likely that these indices can be aligned for a more concise result by matching the critical values taken as a reference. Leão et al. (2005) argued that for the definition of the LLWR's upper and lower limits, it is recommended that critical limits be established according to experimental conditions. Among the soil attributes used to determine the LLWR, it is possible to highlight the PR value adopted in this study (2000 kPa or 2.0 MPa) as being restrictive to root growth. This is because the PR had the greatest influence on the amplitude of this index, which corroborates with Tor-

B
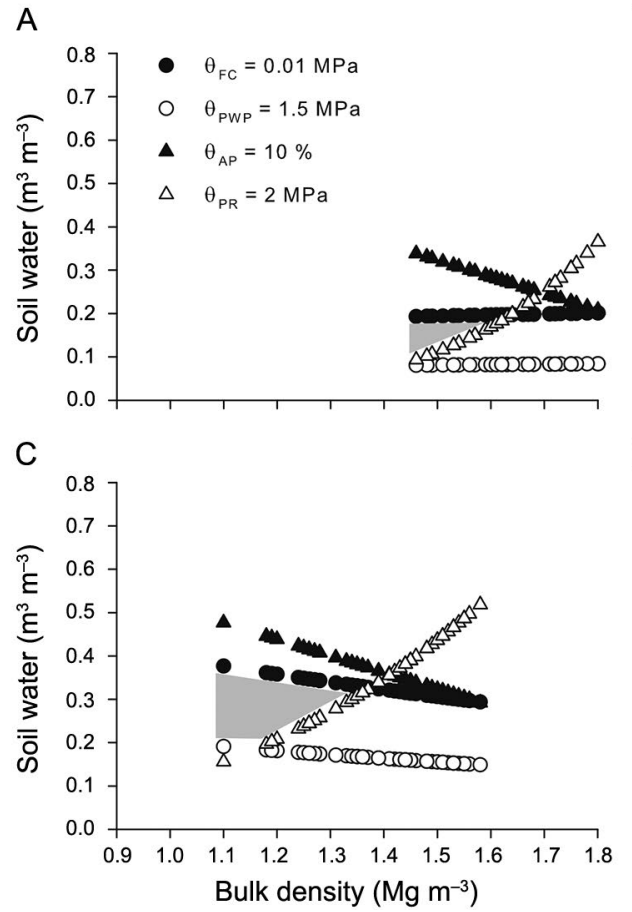

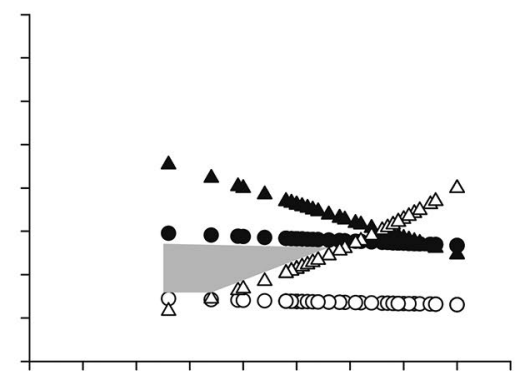

D

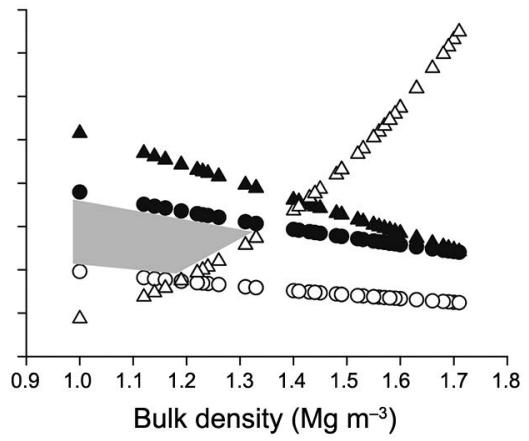

Figure 2 - Least limiting water range values (shaded area) of an Udalf under different management systems: A) CT, B) CNF, C) NF and D) NA. $\theta_{P R}$ = soil water content at penetration resistance value of $2000 \mathrm{kPa} ; \theta_{\mathrm{FC}}=$ soil water content at field capacity; $\theta_{\mathrm{PWP}}=$ soil water content at wilting point; $\theta_{A P}=$ soil water content at $10 \%$ aeration porosity. $\mathrm{CT}=$ soil with corn crop after tobacco crop under a conventional system; CNF = soil with corn crop after native field under a conventional system; NF = native field soil and NA = native area. 
mena et al. (2007), who state that PR is the variable that most often reduces the LLWR. The impact of the PR on the LLWR depends on the critical PR value adopted. Thus, the lower the critical RP value adopted, the lower the $\mathrm{Bdc}$ value. Although the value of $\mathrm{PR}=2000 \mathrm{kPa}$ $(2.0 \mathrm{MPa})$ is suggested as being critical to root growth by Taylor et al. (1966), other research suggests higher values of $2,500,3,000$ and up to $3,500 \mathrm{kPa}$ (Tormena et al., 2007). As an example, Merotto and Mundstock (1999) suggest that severe growth limitation occurs from $3.5 \mathrm{MPa}(3,500 \mathrm{kPa})$. This adaptation of the plants to the high PR occurs mainly in field conditions, where the biopores act as alternative routes for root growth (Ehlers et al., 1983). Thus, the use of the critical PR value higher than the one used $(2,000 \mathrm{kPa})$ might result in Bdc values, which would allow for a superior evaluation of the structural quality of these soils by the LLWR.

The normalized compression curves, for each management system indicate a similar compression behavior (Figure 3). The NF and CT, in general presented, respectively, the highest and lowest deformations with the loads applied. The highest initial $\mathrm{Bd}$ (Table 3) and consequently, the lowest deformation (Figure 3) in the soil under CT are the result of agricultural operations and accumulation of soil pressures. Areas with higher initial compaction (higher $\mathrm{Bd}$ ) or with a background of pressure accumulation might present lower deformation, higher capacity to support the load and lower susceptibility to compaction (CI) with a higher percentage of differences between the native field, $\Delta_{\text {ref }}$ (Table 4). For this reason, it is relevant to know the level of pressure supported by the soil in the past so that additional compaction can be prevented through the knowledge of the capacity to support load values (Table 4).

The $\sigma_{p}$ reductions as a function of $\mathrm{Bd}$ were reported by Rücknagel et al. (2007), and were ascribed to lower cohesion forces and friction between the soil particles. The $\sigma_{p}$ has proved an effective alternative for assessing and identifying soil compaction and can be prevented with superior soil management (Neiva Júnior et al., 2015).
The soil susceptibility to compaction (CI) decreased with the increase in the initial $\mathrm{Bd}$, confirming the results presented by Imhoff et al. (2004). Lower compaction susceptibility might be associated with an increased compaction state, which results in smaller deformations when high pressures are applied, due to the increase in the number of contact points between the soil particles and aggregates. All the management systems presented lower $\mathrm{Bd}$ values in relation to those obtained by $\sigma_{p}$ (Table 4). Bd mean values did not reveal additional soil compaction. However, these values were similar values to the critical Bd according to the LLWR.

Regardless of the degree of soil compactness (CD), the pressures established $(200 \mathrm{kPa}, 1,600 \mathrm{kPa}$ and preconsolidation pressure) presented similar behavior, differing from each other in the three areas under evaluation, with the highest value being attained under CT. The $\mathrm{CD}$ followed the order $\mathrm{CT}>\mathrm{CNF}>\mathrm{NF}$, obeying the highest degradation imposed by the effect of management systems on the soil structure (Table 4).

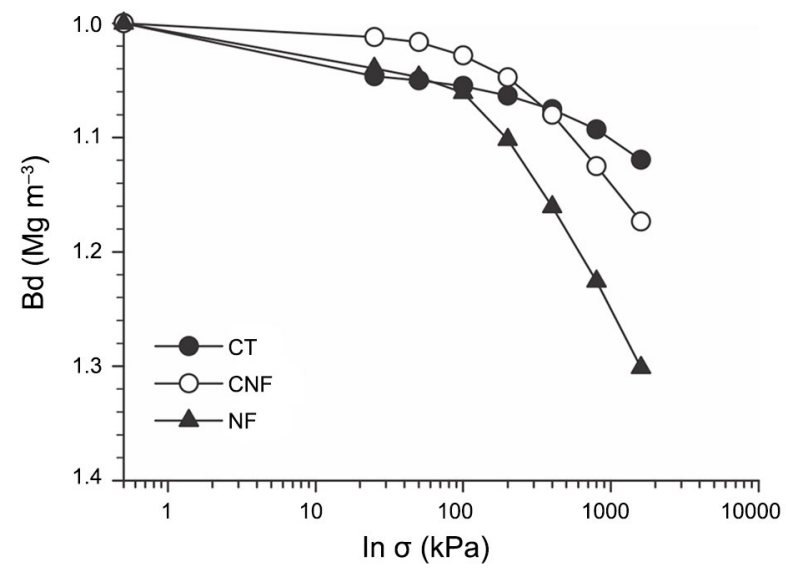

Figure $\mathbf{3}$ - Normalized compression curves of bulk density (Bd) versus applied loads $(\sigma)$ of an Udalf under different management systems. $C T$ = soil with corn crop after tobacco crop under a conventional system; $\mathrm{CNF}=$ soil with corn crop after native field a conventional system and NF = native field.

Table 4 - Mean values of pre-consolidation pressure $\left(\sigma_{p}\right)$, compression index $(\mathrm{Cl})$, bulk density obtained with the pre-consolidation pressure $\left(\mathrm{Bd}_{\sigma p}\right)$, compactness-degree on the $200 \mathrm{kPa}\left(\mathrm{CD}_{200 \mathrm{kPa}}\right), 1600\left(\mathrm{CD}_{1600 \mathrm{kPa}}\right)$ and with pre-consolidation pressure $\left(\mathrm{CD}_{\sigma_{p}}\right)$ of an Udalf under different management systems.

\begin{tabular}{|c|c|c|c|c|c|c|}
\hline Systems of use ${ }^{1}$ & $\sigma_{p}$ & $\mathrm{Cl}$ & $\mathrm{Bd}_{\sigma_{p}}$ & $\mathrm{CD}_{200 \mathrm{kPa}}$ & $\mathrm{CD}_{1600 \mathrm{kPa}}$ & $C D_{\sigma_{p}}$ \\
\hline & $\mathrm{kPa}$ & 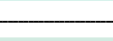 & - & 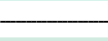 & $\%$ & \\
\hline CT & $315.90 \mathrm{a}$ & $0.15 c$ & $1.75 \mathrm{a}$ & 97.33 a & $92.12 \mathrm{a}$ & $96.83 a$ \\
\hline$\Delta_{\text {ref. }} N F(\%)$ & +86.5 & -57.14 & +15.13 & +9.23 & +21.57 & +4.89 \\
\hline CNF & $173.30 \mathrm{~b}$ & $0.26 b$ & $1.60 \mathrm{~b}$ & $92.15 b$ & $81.79 b$ & $94.86 b$ \\
\hline$\Delta_{\text {ref. }} N F(\%)$ & +2.30 & -25.71 & +5.26 & +3.42 & +7.94 & +2.76 \\
\hline $\mathrm{NF}$ & $169.40 \mathrm{~b}$ & $0.35 \mathrm{a}$ & $1.52 \mathrm{~b}$ & $89.10 \mathrm{c}$ & $75.77 c$ & $92.31 \mathrm{c}$ \\
\hline
\end{tabular}

${ }^{1} \mathrm{CT}=$ soil with corn crop after tobacco crop under a conventional system; CNF = soil with corn crop after native field under a conventional system; NF = native field. $\Delta_{\text {ref. }}(\%)$ : increase $(+)$ or decrease (-) as a percentage of NF. Means followed by the same small letter in the column, did not differ from each other in the LSD test at the $5 \%$ level. 
In general, soil with higher $\mathrm{Bd}$ presented increase in the preconsolidation pressure and, consequently, a high $\mathrm{CD}$. The high $\mathrm{CD}$ might not be favorable to plant development, since favors increased penetration resistance, altering the root system distribution and reducing the plant growth (Silva et al., 2016).

The TOC was higher, around $45 \%$ and $65 \%$ under the NF and NA, compared to CT (Table 5). The greater efficiency of vegetable cover and biological activity increases organic matter content, and, consequently TOC (Salvo et al., 2014). The soil under CT presented the lowest TOC concentration ascribed to conventional management and crop succession (strawberry, tobacco and corn) for at least five years in a row. The reduction in TOC results from the decrease in organic matter physical protection, due mainly to the rupture of aggregates and consequently increase in erosion, accelerated processes of organic matter mineralization and lower organic input in conventional management systems.

According to the statistical test, the highest CFC values were generated under the NA and NF systems (Table 5). The highest CFC in NA is related to the plant root development and residue additions. The systems featuring use with crops (CT and CNF) presented the lower CFC values, which might be justified by the conventional management, which promotes higher exposure of the organic matter to the decomposing agents since it is less protected by stabilization mechanisms.

The agricultural areas cause considerable losses to the coarse fraction of organic matter, mainly ina crop's first years. Carbon associated to the minerals (CAM) is usually less modified by the different management systems, mainly in the short term. However, differences were seen in the CAM regarding soil uses (Table 5), with the greatest values appearing in NA and NF, decreasing in the following sequence: $\mathrm{NA}=\mathrm{NF}>\mathrm{CNF}>\mathrm{CT}$ (Table

Table 5 - Mean values of total organic carbon (TOC), coarse fraction carbon (CFC) and carbon associated to minerals (CAM) of an Udalf under different management systems.

\begin{tabular}{|c|c|c|c|}
\hline Systems of use ${ }^{1}$ & TOC & CFC & CAM \\
\hline & \multicolumn{3}{|c|}{$\longrightarrow \mathrm{g} \mathrm{kg}^{-1}$} \\
\hline CT & $6.3 c$ & $2.4 \mathrm{~b}$ & $3.9 c$ \\
\hline$\Delta_{\text {ref. }} N F(\%)$ & -64.0 & -35.1 & -72.5 \\
\hline$\Delta_{\text {ref. }} N A(\%)$ & -65.3 & -42.9 & -72.1 \\
\hline CNF & $9.7 b$ & $2.4 \mathrm{~b}$ & $7.3 b$ \\
\hline$\Delta_{\text {ref }} N F(\%)$ & -44.6 & -35.1 & -46.7 \\
\hline$\Delta_{\text {ref. }} N A(\%)$ & -46.7 & -42.9 & -47.9 \\
\hline NF & $17.5 \mathrm{a}$ & $3.7 \mathrm{a}$ & $13.7 \mathrm{a}$ \\
\hline NA & $18.2 \mathrm{a}$ & $4.2 \mathrm{a}$ & $14.0 \mathrm{a}$ \\
\hline
\end{tabular}

5). The maintenance of organic matter protected in the soil aggregates increases the period of interaction of the particulate material with clay minerals due to the organic matter of the aggregates longer cycling time, which allows for the complexation reactions to occur more effectively (Six et al., 1998).

The WRC, LLWR, compressibility and organic matter have been acknowledged to establish suitable conditions for plant development, monitoring of management systems and/or conservationist practices are recommended for ensuring the soil structural quality and agricultural yield. Soil physical parameters evaluated in this study may be important to definitions of soil quality under different management systems. However, further investigation of different uses and types of soils are still required to complement the studies carried out up to now.

\section{Conclusions}

The soil water content at field capacity and penetration resistance were the most limiting factors in the definition of the least limiting water, considering bulk density values and all management system evaluated.

The initial mean bulk density value was similar to the critical bulk density obtained by the least limiting water range.

The least limiting water range and the compression parameters indicated negative alterations in the soil structural quality in the $\mathrm{CT}$ and $\mathrm{CNF}$ systems.

Total organic carbon and the carbon associated to the coarse fraction and carbon associated to the minerals fraction were influenced negatively by the conventional system.

The soils with corn after tobacco and corn after native field were shown to suffer more degradation in comparison to the native field areas.

\section{Acknowledgments}

To the Conselho Nacional de Desenvolvimento Científico e Tecnológico (CNPq) for the Masters scholarship granted to the second author, to Embrapa Clima Temperado for making the infrastructure available and to the farmers for offering their area for evaluations.

\section{Author's Contributions}

Conceptualization, writing and editing: Lima, C.L.R; Dupont, P.B.; Miola, E.C.C. Data acquisition: Dupont, P.B.; Miola, E.C.C.; Pillon, C.N. Design of Methodology: Dupont, P.B.

\section{References}

Alvares, C.A.; Stape, J.L.; Sentelhas, P.C.; Gonçalves, J.L.M.; Sparovek, G. 2013. Köppen's climate classification map for Brazil. Meteorologische Zeitschrift 22: 711-728. 
Asgarzadeh, H.; Mosaddeghi, M.R.; Akbar, M.A.; Nosrati, A.; Dexter, A.R. 2010. Soil water availability for plants as quantified by conventional available water, least limiting water range and integral water capacity. Plant and Soil 335: 229-244.

Blake, G.R.; Hartge, K.H. 1986. Bulk density. p. 363-375. In: Klute, A., ed. Methods of soil analysis: physical and mineralogical methods. American Society of Agronomy, Madison, WI, USA.

Busscher, W.J. 1990. Ajustment of flatipped penetrometer resistance data to a common water content. Transactions of the American Society of Agricultural Engineers 33: 519-523.

Cambardella, C.A.; Elliott, E.T. 1992. Particulate soil organic matter changes across a grassland cultivation sequence. Soil Science Society of America Journal 56: 777-783.

Cecagno, D.; Costa, S.E.V.G.A.; Anghinoni, I.; Kunrath, T.R.; Martins, A.P.; Reichert, J.M.; Gubiani, P.I.; Balerini, F.; Fink, J.R.; Carvalho, P.C.F. 2016. Least limiting water range and soybean yield in a long-term, no-till, integrated crop-livestock system under different grazing intensities. Soil and Tillage Research 156: 54-62.

De Jong van Lier, Q. 2014. Revisiting the S-index for soil physical quality and its use in Brazil. Revista Brasileira de Ciência do Solo 38: 1-10.

Dexter, A.R. 2004a. Soil physical quality. Part I. Theory, effects of soil texture, density, and organic matter, and effects on root growth. Geoderma 120: 201-214.

Dexter, A.R. 2004b. Soil physical quality. Part III. Unsaturated hydraulic conductivity and general conclusions about S-theory. Geoderma 20: 227-239.

Dourado Neto, D.; De Jong van Lier, Q.; Botreal, T.A.; Libardi, P.L. 1990. Software for evaluating soil water retention curve using the Genuchten model. Engenharia Rural 1:92-102 (in Portuguese, with abstract in English).

Ehlers, W.; Köpke, U.; Hesse, F.; Böhm, W. 1983. Penetration resistance and root growth of oats in tilled and untilled loess soil. Soil and Tillage Research 3:261-275.

Ferreira, D.F. 2011. Sisvar: a computer statistical analysis system. Ciência e Agrotecnologia 35: 1039-1042.

Gardner, W.H. 1986. Water content. p. 493-544. In: Klute A., ed. Methods of soil analysis: physical and mineralogical methods. 2ed. American Society of Agronomy.

Madison, WI, USA.

Gee, G.W.; Bauder, J.W. 1986. Particle-size analysis. p. 383-411. In: Klute A., ed. Methods of soil analysis. Part 1. 2ed. ASASSSA, Madison, WI. USA. (Agronomy Monography, 9).

Guedes-Filho, O.; Silva, A.P.; Giarola, N.F.; Tormena, C.A. 2014. Least limiting water range of the soil seedbed submitted to mechanical and biological chiseling under no-till. Soil Research 52: 521-532.

Håkansson, I. 1990. A method for characterizing the state of compactness of the plough layer. Soil and Tillage Research 16: 105-120.

Imhoff, S.; Silva, A.P.; Fallow, D. 2004. Susceptibility to compaction, load support capacity, and soil compressibility of hapludox. Soil Science Society of America Journal 68: 17-24.

Islabão, G.O.; Lima, C.L.R.; Vahl, L.C.; Timm, L.C.; Teixeira, J.B.S. 2016. Hydro-physical properties of a Typic Hapludult under the effect of rice husk ash. Revista Brasileira de Ciência do Solo 40: e0150161.
Keller, T.; Silva, A.P.; Tormena, C.A.; Giarola, N.F.B.; Cavalieri, K.M.V.; Stettler, M.; Arvidsson, J. 2015. Soil-Flex-LLWR: linking a soil compaction model with the least limiting water range concept. Soil Use and Management 31: 321-329.

Klute, A. 1986. Water retention: laboratory methods. p. 635660. In: Klute, A., ed. Methods of soil analysis: physical and mineralogical methods. 2ed. American Society of Agronomy, Madison, WI, USA.

Leão, T.P.; Silva, A.P.; Perfect, E.; Tormena, C.A. 2005. An algorithm for calculating the least limiting water range of soil using SAS. Agronomy Journal 97: 1210-1215.

Lima, C.L.R.; Miola, E.C.C.; Timm, L.C.; Pauletto, E.A.; Silva, A.P. 2012. Soil compressibility and least limiting water range of a constructed soil under cover crops after coal mining in Southern Brazil. Soil and Tillage Research 124: 190-5.

Merotto Jr., A.; Mundstock, C.M. 1999. Wheat root growth as affected by soil strength. Revista Brasileira de Ciência do Solo 23: 197-202.

Mishra, A.K.; Aggarwal, P.; Bhattacharyya, R.; Das, T.K.; Sharma, A.R.; Singh, R. 2015. Least limiting water range for two conservation agriculture cropping systems in India. Soil and Tillage Research 150: 43-56.

Naderi-Boldaji, M.; Keller, T. 2016. Degree of soil compactness is highly correlated with the soil physical quality index S. Soil and Tillage Research 159: 41-46.

Neiva Júnior, E.; Rocha, W.W.; Pires, B.S.; Farnezi, M.M.M.; Dias Junior, M.S.; Freitas, D.F.B.; Silva, E.B.; Carvalho, G.A.O. 2015. Compressiblity and penetrability of Latossolo VermelhoAmarelo distrófico (Oxisol) under different management systems and land uses. Revista Brasileira de Ciência do Solo 39: 86-93.

Pires, L.F.; Borges, J.A.R.; Rosa, J.A.; Cooper, M.; Heck, R.J.; Passonia, S.; Roque, W.L. 2017. Soil structure changes induced by tillage systems. Soil and Tillage Research 165: 66-79.

Reichert, J.M.; Suzuki, L.E.A.S.; Reinert, D.J.; Horn, R.; Håkansson, I. 2009. Reference bulk density and critical degreeof-compactness for no-till crop production in subtropical highly weathered soils. Soil and Tillage Research 102: 242-254.

Reichert, J.M.; Rosa, V.T.; Vogelmann, E.S.; Rosa, D.P.; Horn, R.; Reinert, D.J.; Sattler, A.; Denardin, J.E. 2016. Conceptual framework for capacity and intensity physical soil properties affected by short and long-term (14 years) continuous no-tillage and controlled traffic. Soil and Tillage Research 158: 123-136.

Reynolds, W.D.; Drury, C.F.; Tan, C.S.; Fox, C.A.; Yang, X.M. 2009. Use of indicators and pore volume-function characteristics to quantify soil physical quality. Geoderma 152: 252-263.

Rossetti, K.V.; Centurion, J.F.; Sousa Neto, E.L. 2013. Physical quality of an Oxisol after different periods of management systems. Revista Brasileira de Ciência do Solo 37: 1522-1534.

Rücknagel, J.; Hofmann, B.; Paul, R.; Christen, O.; Hülsbergen, K-J. 2007. Estimating precompression stress of structured soils on the basis of aggregate density and dry bulk density. Soil and Tillage Research 92: 213-220.

Rosemary, F.; Vitharana, U.W.A.; Indraratne, S.P.; Weerasooriya, R.; Mishra, U. 2017. Exploring the spatial variability of soil properties in an Alfisol soil catena. Catena 150: 53-61.

Salvo, L.; Hernandez, J.; Ernst, O. 2014. Soil organic carbon dynamics under different tillage systems in rotations with perennial pastures. Soil and Tillage Research 135: 41-48. 
Silva, A.P.; Kay, B.D.; Perfect, E. 1994. Characterization of the least limiting water range. Soil Science Society of America Journal 58: 1775-1781.

Silva, R.B.; Lanças, K.P.; Masquetto, B.J. 2007. Consolidometer: electronic-pneumatic equipment to evaluate soil consolidation. Revista Brasileira de Ciência do Solo 31: 617-615 (in Portuguese, with abstract in English).

Silva, F.R.; Albuquerque, J.A ; Costa, A.; Fontoura, S.M.V.; Bayer, C.; Warmling, M.I. 2016. Physical properties of a Hapludox after three decades under different soil management systems. Revista Brasileira de Ciência do Solo 40: e0140331.

Siqueira, R.H.S.; Ferreira, M.M.; Alcântara, E.N.; Silva, B.M.; Silva, R.C. 2014. Water retention and S índex of an Oxisol subjected to weed control methods in a coffee crop. Ciência e Agrotecnologia 38: 471-479.

Six, J.; Elliott, E.T.; Paustian, K.; Doran, J.W. 1998. Aggregation and soil organic matter accumulation in cultivaded and native grassland soils. Soil Science Society of America Journal 62: 1367-1377.

Somavilla, A.; Gubiani, P.I.; Reichert, J.M.; Reinert, D.J.; Zwirtes, A.L. 2017. Exploring the correspondence between precompression stress and soil capacity in soil cores. Soil and Tillage Research 169: 146-151.
Taylor, H.M.; Roberson, G.M.; Parker Jr., J.J. 1966. Soil strengthroot penetration relations to medium to coarse-textured soil materials. Soil Science 102: 18-22.

Tormena, C.A.; Silva, A.P.; Libardi, P.L. 1998. Characterization of the least limiting water range of an oxisol under no-tillage. Revista Brasileira de Ciência do Solo 22: 573-581 (in Portuguese, with abstract in English).

Tormena, C.A.; Araújo, M.A.; Fidalski, J.; Costa, J.M. 2007. Temporal variation of the least limiting water range of an oxisol under no-tillage systems. Revista Brasileira de Ciência do Solo 31: 211-219 (in Portuguese, with abstract in English).

United States Department of Agriculture [USDA]. 2010. Keys to Soil Taxonomy. 11ed. USDA-NRCS, Washington, DC, USA.

van Genuchten, M.T. 1980. A closed-form equation for predicting the hydraulic conductivity of unsaturated soils. Soil Science Society of America Journal 44: 892-897. 